\title{
Strategic Approach to Job Design: An Issue in Strategy Implementation
}

\author{
Nosheen Jawaid Khan \\ MS Scholar \\ Professor Dr. Sarwer Azhar \\ Director PhD \& Centre for Graduate Research \\ Email: sarwar.azhar@umt.edu.pk \\ Zoofishan Hayat \\ MS Scholar, UMT Pakistan
}

Doi:10.5296/ijhrs.v5i1.6794

URL: http://dx.doi.org/10.5296/ijhrs.v5i1.6794

\begin{abstract}
The field of strategy and strategic human resource management (SHRM) are combined to unveil the "black box" involved in strategy formulation and effective strategy implementation process. The SHRM new focus considered human capital as strategic resource utilized and deployed to strategic jobs that are designed to broaden its focus from task significance to strategically impact on employment of organizational capabilities or competencies at any level in the firm for the effective strategy implementation. Strategic job-design fit contribute to deploy organizational capabilities and competencies for the approach to effective strategy execution that leads to competitive advantage. The strategic capabilities of human capital exhibit certain behaviors that mediate the process of effective strategy implementation. It is suggested that without involvement of internal organization factors (Social Capital and Inter-functional coordination) behaviors cannot be applied appropriately for the convergence process. It is concluded that right pool of human capital should be strategically aligned with strategic jobs while recognizing and deploying organization capabilities and core competencies, manifested through appropriate behaviors rightly applicable through convergence process to smoothen the execution of the strategy.
\end{abstract}

Keywords: Strategic job design, strategic human capital, strategy implementation, behaviors, convergence

Introduction

Today's dynamic business environment is the result of a number of factors including economic, political, social, technological growth, competitive environment, globalization, market turbulence and product innovations (Kumar, Eli, Rajkumar, \& Robert, 2011). The required organizational approach to these radical changes lies in formulating strategies that 
respond to environment for the effective achievement of goals and competing efficiently in the market (Ahmed, Shah, \& Sajjad, 2014). For organizations, strategists mainly focus in answering the where and how organizations should compete. But a significant approach for successful business lies not only in formulating the correct strategy but in implementing it effectively (Heide, Gronhaug, \& Johannessen, 2002). As a matter of fact, effective implementation of an ordinary strategy outperforms poor implementation of an excellent strategy (Sterling, 2003). Thus, strategy implementation has become the center of attention in several studies; however, the main issue is still debatable in that how do organizations carry out strategy implementation effectively. Recent research works in the strategy literature incorporate a new focus on strategy implementation as the pivotal mediating construct in SHRM. Among various organizational factors, leadership, structure and human resource play a significant role in strategy execution (Sorooshian, Norzima, Yusof, \& Rosnah, 2010).

From the beginning SHRM literature has expounded the intermediary processes involved in HR-firm performance link called the "black box" (Becker \& Gerhart, 1996). Particular attention has been given to strategy execution and implementation in progressing towards the exploration of processes and variables which mediate this causal relationship (Becker \& Huselid, 2006). In the context of effective implementation in SHRM, the focus has been on strategic capabilities, derived through the strategic process termed as "strategic jobs". The essence of "strategic jobs" is developing the essential strategic capabilities needed for strategy implementation that eventually impact firm's performance effectiveness (Huselid \& Becker, 2011). The role of strategic job is thus, significant provide a brigde between SHRM and job design literatures (Becker \& Huselid, 2010).

In extant literature, Job design at micro level primarily emphasizes the work structure or work design that is central to individual's professional life. It tends to focus on social and psychological impact of work design elements on the employees (Chan, 2005). On the contrary, SHRM at the firm's macro (strategic) level considers jobs to achieve the organization's strategic goals and clearly finds the job as a means to an end. It explains job to eventually focus on achieving business-level outcomes (like business profitability, shareholder value etc.) that reflect firm's strategic success. Thus notion has therefore, extended a term called "strategic job design" (Becker \& Huselid, 2010) instead of merely "job design". Strategic jobs must have the following characteristics i-e rarity, strategic impact, and measurement of inconsistent individual performance enabling effective strategy implementation (Becker, Huselid, \& Beatty, 2009; Huselid, Beatty, \& Becker, 2005). From the percpective of resource based view (RBV), strategic jobs considers as a strategic resource holding employee's competencies or capabilities which leverage organizational capabilities, non-imitable and rare to a firm that add value to get competitive advantage (Becker \& Huselid, 2006). Strategic job design clearly contribute in developing and employing capabilities or competencies through strategic jobs that organization may need to hold or manifest at any level in the organization which are critical in the execution of the strategy. As in most of the strategy literature, this paper also use both the terms "capabalities" and "competencies" interchangeably (Prahalad \& Hamel, 1990; Day, 1994). 
The organizational capabilities are referred to as an ability to perform a set of activities in a business process with the help of organization assets and knowledge deployed usually in combination, with other organizational processes to affect a desired end (Day, 1994). Whereas the notion of core competencies with respect to organization are referred to as what a firm does particularly well in relation to competitors and describe those competencies that make a disproportionate contribution to ultimate customer value or the efficiency with which that value is derived (Prahalad and Hamel, 1990). Human resource that resides in any organization, utilize their collective capabilities and core competencies to formulate strategies and it is assumed that human resource is the distinctive source that helps in strategy implementation which leads to sustainable competitive advantage (Dunford, Snell, \& Wright, 2009).Human Capital therefore, is comprises of individual's knowledge, competence, and skill deployed in organization (Bontis, 1998), and is an intangible asset forming a necessary part of firm's strategic capabilities.

Given the above brief introduction to the significance of strategy implementation and contributing factor the main focus of the paper is to conceptualize the role of SHRM in developing, recognizing and utilizing strategic jobs in deploying employees' strategic capabilities that further leverage organizations' capabilities or competencies in achieving effective strategy implementation. Further, elaborating the concept of capabilities as an important contributor in strategy implementation the most commonly ignored factor is the behavioral aspect of employees. It is to be understood that capabilities manifest themselves through appropriate behaviors (Dunford, Snell, \& Wright, 2009). Based on a recent study, it is suggested that in successful strategy implementation, organizational characteristics and employee behaviors must complement each other and should be directly aligned with the key success factors of strategies (Olsona, Slater, \& Hult, 2005). This paper also attempts to imply the logic that is necessary to inculcate appropriate behaviors that best manifests capabilities or competencies of the firm in achieving successful strategy execution. In other words to successfully implement strategies and to get desire results certain appropriate behaviors are needed as value added commodities (Riesenberger, 1998). Appropriate behaviors at the individual and collective levels mediates the process of convergence and comprises of (1) Social Capital: the networks of relations comprises of and result in resources that can be utilized for the beneficial purpose of both individual and organizational levels (Nahapiet \& Ghoshal, 1998) (2) Inter-functional Coordination: involves coordination among department and employees in utilization of resources available to a firm in creation of superior value (Narver and Slater, 1990). The paper will focuses on the notion of convergence needed for strategy implementation. Convergence includes intangible resources or asset, which help firms to develop and implement their strategies and to get desire result at macro level (Ray, Barney, \& Muhanna, 2004). Further, it will focus on the logic that will help in creating a strategic job design-strategy fit; where strategy fit implies (1) strategic human capital deployed at strategic jobs must reflect competencies that should match with core competencies of the firm (2) and also utilizing strategic capabilities of human capital that is needed with firm's capabilities in driving effective strategy execution. Objectives of this paper are; 
1. To conceptually delineate the role of SHRM in utilizing the strategic human capital to achieve effective strategy implementation while exploring the role of job design there in. To create the strategic job design-fit between strategic human capital and strategic job design.

2. To identify appropriate behaviors those best utilize capabilities or competencies of the firm in effective strategy implementation process.

3. To identify the mediating role of behaviors in convergence process (Social Capital and Inter-functional Coordination) that leads to competitive advantage.

The rest of the paper will utilize on the following structure. The second section of this paper will deal with literature on strategy implementation followed by contribution to successful implementation. The theoretical framework section will propose the model and its logic which will also include the propositions developed therein. Finally the paper will present its discussion and conclusion drawn while identifying future research areas.

\section{Literature}

Strategy implementation

In literature strategy is referred to as action plan which consists of incorporated goals, policies and series of activities that are operationalized within an organization (Mintzberg, 1994). Organizational performance is a measure in terms of how well an organization is achieving its goals, the actual output (results) as measured against its intended goals and objectives. The significance of strategy implementation during the 2000s had shown positive effect on the organizations' performance (Hitt \& Hoskisson, 2011).Both the elements relevant to strategy; i-e appropriate formulation and correct implementation are essential to success of business (Heide, Gronhaug, \& Johannessen, 2002) however, the effective implementation of an ordinary strategy can outperform the poor implementation of an excellent strategy (Sterling, 2003). At strategy formulation stage, sometimes there are chances for identification of wrong internal and external factors of strengths and weaknesses as well as key success factor for the business. A correctly formulated strategy cannot be considered as an effective strategy until its appropriate execution creates value for the firm (Johannessen, 2002). Studies show that $66 \%$ of the organizations failed to effectively implement the organizational strategy (Johnson, 2004) while $95 \%$ of the employees misunderstood the organizational strategy (Kaplan \& Norton, 2005) also only $63 \%$ of the organizations are able to achieve their financial objectives and strategy implementation targets (Steele, 2005).

Indeed, strategy implementation is the most challenging and complicated phase in the organization's strategic management (David, 2011). Although a well-designed strategy can progress and improve the strategy implementation within a changing business environment, but these changes also demand controlling the progress of strategy implementation (Norton, 2008).However, organization structure, human resource, leadership, and technology and information system are number of factors identified which impact strategy implementation (Sorooshian, Norzima, Yusof, \& Rosnah, 2010). 
Strategic Human Resource Management

It has always been a consistent struggle for human resource management function in explaining its place in organizations (Drucker, 1954; Stewart, 1996). With the emergence of strategic human resource management (SHRM) as a contiguous field of HRM in 1980s, constantly focused on establishing HR's positioning within the business strategy framework, to create its value for the firm. (Wright, Dunford, \& Snell, 2001a). It is being developed over a period of time in organizations with the aim of securing superior performance in terms of achieving financial results. However, with recent research work in the strategy literature, SHRM has a new emphasis which is directed towards strategy implementation, and forms a pivotal mediating construct in SHRM. It is attempting to create a fit between the HR architecture comprises of employee's and organizational performance relationship, strategic capabilities and competencies, policies along with business processes that are the basis of HR's role in achieving competitive advantage by implementing strategy (Becker \& Huselid, 2006). Wright and McMahan (1992) defined strategic human resource management as "the pattern of planned human resource deployments and activities intended to enable the firm to achieve its goals". Miller (1987) defined Strategic Human Resource Management practice as "the decisions and actions, which concern the management of employees at all, levels in the business, and is related to the implementation of strategies directed towards sustaining competitive advantage". SHRM in the field of research has explored in linking firm strategy (corporate or business unit level) and HR strategy, and also discussed impact of HRM explicitly on strategy execution and is now engaged in strategy formulation (Snell, Shadur, \& Wright, 2001).It is to be noted that traditional micro (functional) research in HR has focused on the impact of individual HR practices on individuals, while macro (strategic) HR research has focused on the impact of HR management systems on groups or organizations (Wright \& Boswell, 2002). SHRM as a new perspective focused on contributing in the management of people and it aimed in integrating human capital as one of the core element of business strategy and execution of strategy in achieving competitiveness (Inyang, 2010).

Moreover, SHRM is concentrating on managing firm's resource that contributes much too strategic capabilities of a firm in achieving competitiveness. (Lengnick-Hall, Lengnick-Hall, Andrade, \& Drake, 2009). It includes process in developing practices, strategies, resources and policies that collectively play role to enhance organization's strategic capabilities in accomplishing its strategic goals (Mello, 2002).

\section{Strategic Job Design}

Strategic business processes or activities are one of the elements of strategy implementation which mediate the link between HR and the financial outcome. The struggle in research to explore the notion of "black box" between HR-firm performance relationship suggested new direction for SHRM to identify primary strategic processes that lies in black box. Strategic Jobs are the result of effort made in SHRM research to explore the prominence of this focus (Becker \& Huselid, 2006). Previously, the focus in job design literature was mainly at micro level that only signified the nature and structure of work itself and focused as it's influenced on the social and psychological impact on individuals in those jobs (Becker \& 
Huselid, 2006). Job design characteristics include skills, task learning, task significance and feedback these are motivational potential asset to the job (Ahmed, Shah, \& Sajjad, 2014). To perform particular job varied and numerous skills are used by the individual to do that particular work. At individual's motivation level task learning plays a role in making one understand the way to perform particular job task given to him. The level of getting feedback about an individual's performance against set objectives is defined as task feedback (Saavedra \& Kwun, 2000). Task importance is how important is the job for one's personal motivation level and the impact of the job on other individuals (Hackman \& Oldham, 1980).

The idea that job can be a source to impact strategy has already been discussed in literature (Conger \& Kanungo, 1988; Spreitzer, 1995). However, the new theme which encapsulates the integration of capabilities and strategy requirement in the form of strategic job designs has significantly contributed as an effective factor in execution of organization's strategic capability and connecting different HR architecture and HR's strategic impact. Strategic job is not fixed to particular level in organization, infact all level of job could be designed as strategic jobs. It denoted by certain characteristics such as : (1) rarity, which means there are less than 15 percent of strategic jobs at any level in an organization, (2) strategic impact : means job are of strategic nature referring strategic capability that can be utilized directly and affect organization's ability to successfully implement strategy which ultimately leads to firm performance (Huselid, Beatty, \& Becker, 2005; Huselid, Becker, \& Beatty, 2005).Further in the same vein it suggests that some jobs are more strategic in nature as compared to other, and requires that needs to be handled accordingly, (3) finally employee performance variability, shows differentiation between high and low workforce performance portrayed in terms of improvement and involvement of an employee performance (Becker \& Huselid, 2006; Becker, Huselid, \& Beatty, 2009).

Strategic jobs have the characteristic to play strategic role in impacting organization's strategic capability to implement strategy that's why need of broadening the construct of task significance to strategic significance is significant to new SHRM research. It will help job design researchers in SHRM to establish that a specific job is indeed a strategic job which will impact the organization (Becker \& Huselid, 2010). Strategic jobs are related to the firm's strategic capabilities or competencies and help to deploy them for the operationalization of strategy implementation. This perspective is in the link with RBV which enjoins that capabilities are intangible organization assets which enable firms to create and implement strategies (Barney, 2001). A further objective of focusing on capabilities and competencies is the likelihood of their impact and influence on the outcome of other resources of the firms which include processes and procedure. In this context a particular attention is on those strategic business processes that require inputs with high human capital content.

SHRM has broadened the concept of "job designing" as strategic in context by achieving business outcomes, that directly reflect success in achieving strategic results. Business outcomes like (profitability, shareholder value, etc.), or mediators (strategic capabilities) that clearly drive that strategic success (Becker \& Huselid, 2010). There is need of recognizing 
job performance in strategic jobs that might add value and contribute to competitive advantage of the firm. Baron (2010) encourages job design scholars to consider moving from a focus on micro-level individual outcomes to firm-level outcomes. Another perspective in designing strategic jobs, emphasize employees to identify their roles and encapsulate their performance by certain behaviors and relationships that might help to add disproportionate value in the firm performance. Their extended job related tasks and relational behaviors might shape up interactions and relationships with others at work that collectively make their jobs more strategic extended the notion of strategy execution (Wrzesniewski \& Dutton, 2001)

\section{Strategic Human Capital}

Human capital resource is one of the important elements within this debate. In its historical perspective it is identified with Adam Smith "the acquired and useful abilities" of individuals as a source of "revenue or profit". This aspect of human capital is rooted in the economic perspective, as an outcome of this Becker (2002) formulated the definition of human capital as knowledge, information, ideas, skills, experience, education and health of individuals (Ployhart \& Moliterno, 2011).As an extension to the economic perspective it can be proposed that people should be considered as important asset similar to physical assets that contribute in organizations and businesses development and growth and should not be treated as expense. Further literature on intellectual capital also suggests that human capital is its core element in intellectual capital and it comprises of individual's knowledge, competence, skill, capability and innovation (Bontis, 1998).

In psychological perspective, it has been emphasized that new focus should be on examining and implementing HR process and practices impacting people through which human capital should be developed in an individual rather than individual's choice to develop characteristics of human capital in himself/herself (Bell \& Kozlowski, 2008). This notion is similar to SHRM, in which focus is shifted from people towards organization imposing practices that affect human capital rather than the human capital itself (Wright \& McMahan, 2011). The integration of SHRM and human capital tends to focus at employee-level characteristics that pool human capital and consider looking at human capital as strategic resource rather than strategic asset according to RBV. Recognizing existing strategic resources called as "intermediate goods" (Amit \& Shoemaker, 1993). The role of intermediate goods impact fits within the black box in relation between the HR architecture and firm performance. The notion of strategic human capital can be taken as an intermediate good significantly highlight the notion of "connectedness" and location of strategic capabilities within a strategy implementation system (Becker \& Huselid, 2006). RBV focus on resources and assets that are required for organization capabilities, described as important ground for performing series of activities. This notion describes human capital as core element in a system of capabilities that implement strategy. 


\section{Al Macrothink \\ International Journal of Human Resource Studies \\ ISSN 2162-3058 \\ 2014, Vol. 5, No. 1}

Capabilities, competencies and Strategic capability

In the continuity to describe strategic job and strategic human capital as a helpful tool in deployment of organization capabilities and competencies, firstly it is important to describe all the terms capabilities, competencies and strategic capability of firm. Accumulated assets are the resource which needs to establish successful business and capabilities is the binding tool that combine these assets and facilitate in their effective deployment (Day, 1994). Capabilities are rooted in the organizational activities and practices that they cannot be imitated or copied easily. Capabilities are accumulated knowledge and skills, applied through organizational processes that help firms to integrate set of activities and make use of their assets. However, there are some unique capabilities that help a firm to take market position unique and valuable in opposite to its competitor and thus business resulted superior performance with in competitive environment (Hooley, Broderick, \& Möller, 1998). These are the distinctive capabilities are called as core competencies. Core competencies make disproportionate contribution in creation to superior value for the customers (Prahalad and Hamel, 1990). The strategic capabilities are important in terms of contributing factor in achieving sustainable competitive advantages and superior profitability (Becker \& Huselid, 2006). All the capabilities and competencies should be manifest through appropriate behaviors and application of those behaviors is with the help of some organizational factors.

Internal Organizational Factor

Social capital

In its true sense, the term social capital was actually meant to describe the relations of the individuals and other resources for the development of social organizations (Jacobs, 1961). Modern researches has used this term to describe relations inside and outside the family at broader level of social phenomena (Coleman, 1988), relationships internal and external to the organization (Burt, 1992), the interaction of organization and market (Baker, 1990), and life of comman people in modern societies (Putnam, 1993). Other studies has also mention social capital as a very productive and effective source of organization that is supportive not only to the firm performance as well as to the individual personal attainment in organization (Lin, 1986). Also that social capital is as significant as physical and human capital in organizations to a firm's business operations (Burt, 1992).In contemporary studies a theoretical model of capital is presented as how it support, facilitate and helps in creating value for the firms (Ghoshal, 1994). On the same pattern more concepts related to role of social capital in creating value to the firm have raised that strengthened the concept (Nahapiet, 1997).

Few of scholars, however, have conceptualized a broader definition of social capital, including not only social relationships, but also the norms and standards linked with them (Putnam, 1995). Social capital, which is defined as knowledge embedded within, accessible to and exploited by exchanges among individuals and through their ties and network (Nahapiet \& Ghoshal, 1998). Social capital is stated as the networks of associations comprises of and result in resources that can be utilized for the beneficial purpose of both 
individual and organizational levels. Social capital at the individual level, social defined as the resources entrenched in interpersonal relationships. Secondly at the organizational level, it has been distinct as the value embedded in associations formed by actors to drive behaviors engaged in doing combined action (Freel, 2000).Further three dimensions of social capital was introduced and widely accepted among researchers includes structural, cognitive and relational that create the valuable intellectual capital in an organization (Nahapiet \& Ghoshal, 1998).

\section{Inter-functional Coordination}

Inter-functional coordination has become a cultural aspect in many contemporary organizations and has a very significant impact on organizational (Smith, 1994). Previous research argues that the major factors influencing organizational performance were marketing and technology related human resource.

Inter-functional coordination is referred to as the collaboration and cooperation of different inter-departmental functions within a firm for the purpose of establishing relationships, sharing values, knowledge, and information through strong communicating to meet organizational goals and objectives (Narver \& Slater, 1990). Inter functional coordination exhibits the capacity and capability of different functional areas to work on the interest that is for the better of the organization as a whole while putting aside own perspective and rigid behaviors. It represented as one of the forms of internal social capital.

In extant literature social capital is presented as an external resource of the organization, intern-functional coordination can conceive as internal sources of social capital within the organization (Tsai, 1998). An intern-functional coordination is a social resource that is embedded within an organization and works as a crucial asset in getting the most out of organizational performance (Florin, 2003).Inter-functional coordination is referred to as a structural system that helps to achieve common objectives of the organization. It is conceptualized as a resource to enhance effective communication, cooperation, and cohesiveness, by establishing the relationships between various areas having different functional skills, knowledge, and experience (Ruekert, 1987). It has been established that higher organizational performance is an outcome of effective inter functional communication and coordination (Damanpour, 1991).

In short, inter-functional coordination facilitates the achievement of organizational objectives by transforming the capabilities of human capital into a combined and unified bundle of resources (Pisano, 1997). It is assumed that an organization can effectively work only when certain conditions take place: (1) If employees are capable and willing to communicate with each other (2) exhibit required behaviors (3) work for a common goal. The two aspects that need to be noticed, it is significant for organization superior performance that individuals are able to work together, and derive satisfactions in the process of collaboration; in this way organization becomes efficient and effective (Mangham, 1986).

Based on the above presented literature this paper proposes the conceptual model in fig 1 


\section{Al Macrothink \\ International Journal of Human Resource Studies \\ ISSN 2162-3058 \\ 2014, Vol. 5, No. 1}

below. The rest of the paper will present the proposition developed from the conceptual framework and end with conclusion drawn.

Conceptual Model

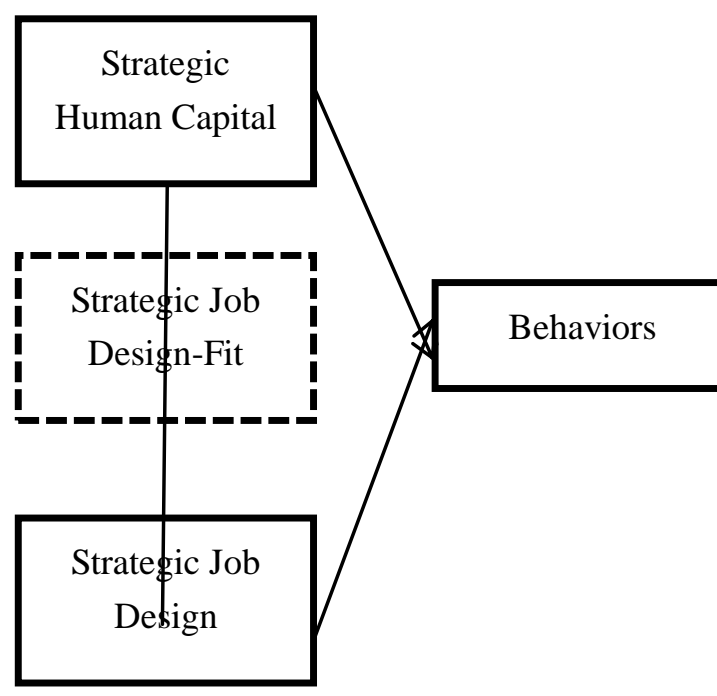

Convergence

- Inter-functional

Coordination

- Social Capital

Figure 1: A Conceptual Model

Three main stages of strategic management are the strategy development, its implementation and evaluation. The significance of strategy implementation is observed during the era of 2000s when the strategic management has positive influence on the firm's performance (Thompson \& Martin, 2005). The essential logic of successful business lies in both the correct strategy formulation and its effective implementation .If the strategy is formulated correctly, it would not create value for the organization until its ineffectiveness in implementation remains there (Heide, Gronhaug, \& Johannessen, 2002).Generally, businesses articulates superior performance if the strategy is implemented in an effective manner. One of the major hurdles in effective strategy implementation is when employees miss-conceptualize their organization's strategy. On the other hand one of the important organizational factors significant in strategy implementation is the human resource .It has also been studied that there exist a significant relationship between strategy and human resource in implementing the strategy (Sorooshian, Norzima, Yusof, \& Rosnah, 2010). The resource base approach to strategy implementation assumes that human resource is a major source for achieving competitive advantage in the firm (Dunford, Snell, \& Wright, 2009). However, new focus of strategic management consider human resources as value-added commodity; also broaden the focus of human resource management research from an individual perspective (micro) approach to an organizational perspective (macro) or strategic approach (Richard \& Johnson, 2001).

Strategic Human Capital, Strategic Job Design and Strategy Implementation 
To establish a concrete relationship between HR-Performance, in recent strategy literature much attention has given to "implementation" which is an opportunity for extending theoretical analysis and conceptualization. HR-performance link cannot be established alone. In new SHRM theory it has been recognized that there are some intermediate outcomes, playing a part creating an indirect link (Becker \& Gerhart, 1996).Implementation plays a similar role in new SHRM perspective in terms of HR-performance link as well as HR-strategy fit notion. Rather than considering implementation as an independent theoretical construct, SHRM theory has relied on the implication that an appropriate match between the HR architecture and strategic choice (Strategy positioning) results in effective implementation (Becker \& Huselid, 2006). This paper proposes to consider that implementation will not be effective alone, until HR architecture that is composed of the systems, practices, competencies, and employee performance behaviors converges with its strategic approach reflecting the management and deployment of the firm's strategic human capital (Becker \& Huselid, 2006).As it is already recognized by RBV theorists that "the ability to implement strategies is, by itself, a resource that can be a source of competitive advantage" (Barney, 2001, p. 54) .There is always being an effort in elaborating the gap underlining the notion " black box" which establishes a theoretical and empirical specification of HR-performance relationship. SHRM suggests some strategic process involved in that black box. The paper current focus is to look at strategic approach to HRM as an essential component of the strategic processes involving HRM activities that will act as a resource contribution for strategy implementation and competitive advantage of a firm (Huselid, 1995). One of the HRM activities is job design but in achieving SHRM effectiveness to its strategic approach conceptualizion of "strategic job design" has been proposed which forms the basis for deployment and management of organization capabilities which recognizing core competencies of the firm. To highlight the strategic process involved in designing jobs significantly given a prominence to a new term that is called as the "strategic job" (Becker \& Huselid, 2006).

If we look in the context of strategic capability of SHRM, it is involved in creating strategic process like designing strategic jobs as discussed, then to match organization capabilities with particular type of human capital with strategic capability is required that could portrayed to be a strategic value for the firm. Strategic approach to human resource is to recognize and deploy unique human capital skills, competencies, strategic capabilities and knowledge at strategic jobs that ideally work to implement strategy leads to enhance firm's competitive position and add value economically (Huselid, Jackson, \& Schuler, 1997; Snell \& Dean, 1992) .The firm's ability to employ organizational capabilities is facilitated by strategic jobs in relation to identify, deploy and incorporate strategic human capital to enhance the productivity in terms of effective strategy implementation (Russo \& Fouts, 1997). With respect to RBV speculates that human and organizational resources, more than physical, technical or financial resources, can provide a firm with sustained competitive advantage because they remain scarce or hard to duplicate, have no direct substitute (Wright \& McMahan, 1992). 


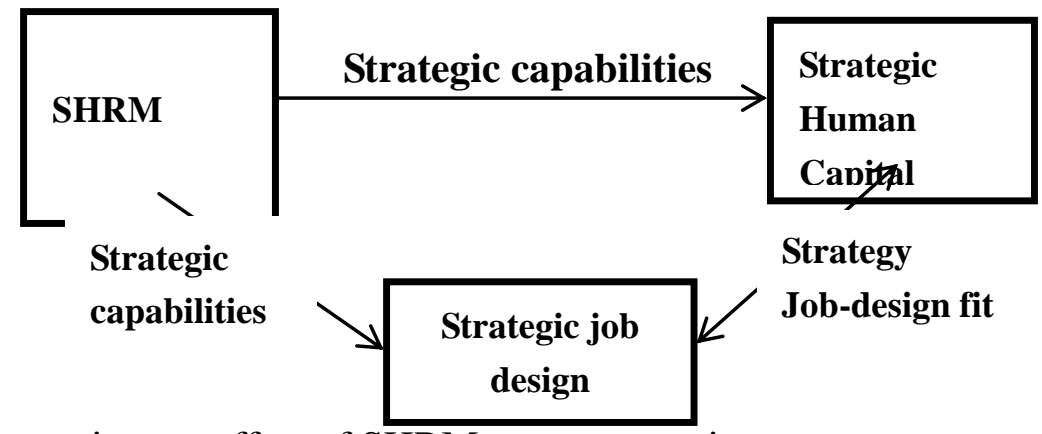

Figure 2: A continuous effort of SHRM new perspective

Proposition 1: The strategic capability of SHRM is in recognizing strategic jobs that facilitate the deployment of organization capabilities at any level with best strategic human capital along with strategic capabilities to be designated at those jobs for effective strategy implementation.

The questions raised and need to be answered are what do we mean by strategic job? What are its components? How they are to be designed strategically to fit in human capital of strategic capabilities? What type of human capital is required and its components?

It is needed to focus that a firm involved in designing strategic processes would implement strategic capabilities of firm, which further provides a theoretical prominence towards strategy implementation and execution process. As the ability to implement strategy itself is a resource that could be a source for competitive advantage of firm (Barney, 2001).The SHRM focus on job design is broadened from micro-level individual outcomes to firm-level outcomes (Baron, 2010). These organizational outcomes of job design means that these strategically impacting on business strategic success through utilization of strategic capabilities of firm. The end objective of job design encourages in implementing strategy effectively when it facilitate firm's ability to perform series of activities in business process and also identifies distinct capabilities of the firm that create value for the customers. Job design involves the motivating potential of a job such asset of skills, task learning, task significance and feedback. Skills means usage of various individual's skills or competencies to perform some activities that is essential in business process, task learning is the degree to an individual perceive piece of work and accomplish the designated activities. Task significance is the degree to which a job has importance for one's personal motivation level and the impact of the job on other individuals (Hackman \& Oldham, 1980). Task feedback is an opportunity to evaluate how effectively an individual is performing specific task (Richard, Saavedra and Seog, 2000). In strategic job design construct of task significance is extended to strategic significance. Previously it was constructed to describe the impact of the job on other individuals. The notion of task significance defined and extended the impact on individuals to its impact on the organization. This determines that which job are strategically impacting and facilitating organization capabilities to be deployed at any level, and how it contributes in the process to accomplish strategy implementation effectively. The increasing effort to strategy implementation suggests important opportunities to focus on intermediate outcomes that 
complete the process from developing strategic process till strategy implementation. Thus, it is to establish first while designing jobs that which one is the strategic job within the firm that is helping organization to deploy and manifest its capabilities at any level.

Proposition 2: Strategic Job design identifies strategic jobs as contributing factor in deploying organizational capabilities and competencies in achieving effective strategy implementation.

\section{Strategy Job-design fit}

The challenge is to distinguish which job contributes to the organization's effective strategy implementation. The strategic jobs are essential and aligned to the company's strategy, directly contributing in capabilities and competencies of organization that derives implementing company's strategy. But alone strategic jobs are useless until people designated to these jobs have strategic capabilities that cordially integrate with organization capabilities and competencies to accomplish the series of activities in any business process (Huselid, Beatty, \& Becker, 2005). Firstly, SHRM while engaged in strategic process to design jobs must understand what is company's strategic capabilities and core competencies, ability to certain set of activities essential in achieving competitive position and superior value, this will help in recognizing what jobs would help to employ these capabilities that leads to effective strategy implementation. Secondly, SHRM must involve in recognizing, managing and utilizing human capital that should have strategic capabilities to fit for these strategic jobs. It means human capital (skills, knowledge, strategic capabilities and competencies) should match company's capabilities or should have been created in a way that contributes in creating a value for the organization by achieving effective strategy implementation.

Consider the case of Walmart; it competes on its logistic capabilities, not the customer buying experience. So, the job designed for employing logistic capabilities will be called as strategic jobs and human capital with competencies and strategic capabilities will allocated to strategic jobs to create value for customers (Huselid, Beatty, \& Becker, 2005). The description of a strategic job is starting from identifying firms' capabilities or core competencies, which leads to assessment of a job's role in employing organization's ability to perform series of activities as response (strategy) to achieve competitive position. The attribute of strategic job (1) Rarity; less than 15 per cent of a firm's jobs are contributing to gain competitive advantage of firm and directly related to firm's strategy, (2) Strategic impact; it directly affect a firm's ability to execute its strategy through employment of strategic capability, (3) Variability; the gap between high and low employee performance (Becker, Huselid, \& Beatty, 2009). Consider the example in banking industry, if any bank is competing on the basis of customer service and relationship capabilities, jobs that will have a touch point with customers will be considered as strategic jobs. Bank needs to manage and utilize its human capital and must have to develop strategic capabilities in them by informing the employees, which organizational capabilities and core competencies of bank that is essential in achieving strategy execution effectively. Now, the human capital serving strategic jobs with their skills, knowledge and capabilities will intend to maintain and establish long-term 
relationship with customers that helps firm to sustain its competitive advantage. These strategic jobs would impact and contribute in strategy execution of the firm along with disproportionate contribution in the human capital's performance.

Proposition 3: Strategic job design-fit able to deploy strategic human capital with skills, knowledge, strategic capabilities and competencies that helps in manifestation of organizational capabilities and competencies in the process of strategy implementation.

Moderating role of Behaviors in Strategy Implementation

Organizational capabilities are best manifested through employee's behaviors. It has been established that certain set of behaviors and attitude is required from employees to get aligned with firm strategy and certain HR activities posit and produce a unique set of responses from employees (Cappelli \& Singh, 1992).

In one aspect employees were treated as organizational asset, but treating them strategically in a firm it is necessary to consider them as a resource. One of the roles of strategic manager is to focus on human capital who achieves organizational objectives and execution of strategies effectively (Wright, Dunford, \& Snell, 2001a). One of the SHRM activities like strategic job design will utilize and induce human capital strategically and encourage employees with strategic capabilities to stay in the firm with certain type of positive behaviors that most effectively deploy organization capabilities. These behaviors will strengthen the process of strategy implementation. Due to competitive and turbulent environment, organizations must have aligned their HR activities strategically to gain competitive advantage (Kramar, 1992). In order to achieve effective strategy and competitive advantage, it also becomes significant for firms to focus on already developed employees' attitude and behaviors and also on HR activities that drives human capital in a way that exhibits certain type of behaviors help in strategy implementation process. This becomes important in various businesses especially for knowledge-based organizations it is required to motivate and retain their human capital to create, retain and sustain competitive advantage (Finegold \& Frenkel, 2006).Some researchers in strategic HRM have emphasized on creating a fit between a firm's strategy and the types of behaviors exhibited by employees. Strategic HRM scholars have relied extensively on the concept of fit, and these fit relationships seem to involve three generic classes of HR variables:

HRM practices, employee skills, and employee behaviors (Schuler \& Jackson, 1987).But this paper trying to elaborate that due to strategy job-design fit certain behaviors could be an outcome that mediate the strategy implementation process. When SHRM performed an activity of deploying the human capital of strategic capabilities on strategic jobs, strategy must be first clarified to employees designated to those jobs. This is significant to the role behaviors performing by each employee that is considered to be strategically important. Their behaviors will impact positively on the strategy implementation due to know-how they have already gained about competing strategy of the firm. They act in a particular behavior and attitude as their performance will matter in the variability of performance in an organization. 
Proposition 5: Appropriate behaviors are the outcome of strategic job-design fit help to manifest organizational capabilities and competencies to mediate the process of strategy implementation

Internal organizational factors and Strategy Implementation

Once the required behaviors by employees are exhibited and identified, they need convergence process for the applicability of those behaviors. There are number of internal organizational factors those help in deviation of behaviors that create strategy fit in the execution of the strategy. This paper will focus on social capital and inter-functional coordination that is required by employee working in a firm. Inter-functional coordination as explained is the cooperation and collaboration between employees working in a firm for sake of resource sharing i-e knowledge, information and experience to achieve organizational goals (Narver \& Slater, 1990). It is collectively done to create a value for the organization. Inter-functional coordination is a part of popularized concept of social capital refers to beneficial outcome from the relationship formed among employees. Social capital resides within organization that is to build a relationship within and outside the organization. Human capital deployed at strategic jobs participating in the execution of strategy implementation required behaviors that should appropriate for this strategic process. But once behaviors are developed, identified and managed, they are to be exhibited through proper channel that would be a step towards implementation process. The convergence process in which employees are engaged is the willingness to share the resources within an organization that can be developed through inter-functional coordination culture of behavior, access and control them exchanged through relationships with others in order to gain benefits or acquire social capital. Another aspect is how one group within an organization through relation of trust and trustworthiness can be beneficial for other group of employees (Mohan \& Mark, 2005). The human capital at strategic job through social capital able to share resources, coordinate and build relationship with the employees doing non-strategic jobs, in this way both the groups with collaborative effort confine themselves in the strategy implementation process to achieve competitive advantage.

Proposition 6: Social capital and inter-functional coordination is the convergence process within organization through which employee behaviors are applied appropriately for the effective strategy implementation that leads to competitive advantage

\section{Conclusion and Future Directions}

The SHRM new focus broadened to organizational level, working for the benefit of business outcomes in terms of financial or strategic value. Strategic HRM new emphasize is to smoothen the process of strategy implementation involved in developing practices or activities that use strategic capabilities of firm to gain effective strategy execution. A strategic job designing is the SHRM activity that directly impact strategically in implementation process. Strategic jobs contribute in correct deployment of organizational capabilities and 


\section{Al Macrothink}

competencies that manifest strategy execution. Firms identify and employ strategic human capital to fit in strategic jobs is to be portrayed as strategic capability of a firm.

SHRM signifies the importance of their strategic human capital in the firm as it helps a firm to conceive or implement strategies that improve its efficiency and effectiveness (Barney, 1991, p. 106). Human capital strategic capability is recognized, utilized and managed at its best manner when designated to strategic jobs, because it should matched with organizational capabilities and core competencies Indeed, all firms rely to at least some extent on human capital, SHRM emphasize the variability that not all employees possess knowledge and skill that are of equal strategic importance.

Organizational capabilities are best manifested through behaviors and appropriate behaviors are important component that unable firm to identify the specific linkages between employee's efforts and resulting output in the strategy execution process. The strategic capability resides in human capital along with certain behaviors are able to achieve effective strategy implementation. It is established that without strategic capability in human capital, certain behaviors cannot be exhibited, and that the value of human capital can only be realized through appropriate exhibited behavior.

It is needed to continuously monitor the human capital that should be aligned with the strategic capabilities of the firm. The strategic human capital pool refers to the stock of employee skills and strategic capabilities that are to be utilized through strategic jobs to achieve strategic impact, along with appropriate behaviors. These behaviors applied through establishing long-term relationships within group of employees and in which cooperation, trust, and knowledge sharing is critical (Barney, 1991, p. 102).

The future direction needs to focus on identifying the differential SHRM activities and practices for human capital deployed on strategic and non-strategic jobs. There is a need to specify the impact of non-strategic jobs in value addition of strategy execution process in contrast to strategic jobs. 
Reference

Ahmed, S., Shah, M. U., \& Sajjad, M. (2014). Examining Human Capital and Job Design: Mediating through Management Expertise to Achieve Sustainable Competitive Advantage. Journal of Basic and Applied Scientific Research, 4(1), 191-199.

Baker, W. (1990). Market networks and corporate behavior. American Journal of Sociology, , 96; 589-625.

Barney, J. (1995). Looking inside for competitive advantage. Academy of Management Executive, 9(4), 49-61.

Barney, J. B. (2001). Is the resource-based "view" a useful perspective for strategic management research? Yes. Academy of Management Review, 26, 41-56.

Baron, R. A. (2010). Job design and entrepreneurship: Why closer connections $1 / 4$ mutual gains. Journal of Organizational Behavior, 31, 370-378.

Becker, B. .., \& Huselid, M. A. (1998). High performance work systems and firm performance: A synthesis of research and managerial implications. Research in Personnel and Human Resource, 16, 53-101.

Becker, B. E., \& Huselid, M. A. (2006). Strategic Human Resources Management: Where Do We Go From Here? Journal of Management, 32, 898.

Becker, B. E., \& Huselid, M. A. (2010). SHRM and job design: Narrowing the divide. Journal of Organizational Behavior, 31, 379-388.

Becker, B. E., Huselid, M. A., \& Beatty, R. W. (2009). The differentiated workforce: Transforming talent into strategic impact. Harvard Business review.

Becker, B., \& Gerhart, B. (1996). The impact of human resources management on organizational performance:Progress and prospects. Academy of Management Journal, 39, 779-801.

Bell, B., \& Kozlowski, S. (2008). Active learning: effects of core training design elements on self-regulatory processes, learning, and adaptability. The Journal of Applied Psychology, 93(2), 296-316.

Burt, R. S. (1992). Structural hales: The social structure of competition. Cambridge, MA:

Harvard University Press .

Cappelli, P., \& Singh, H. (1992). Integrating strategic human resources and strategic management. Research frontiers in industrial relations and human resources.

Chan, D. (2005). Current directions in personnel selection research. Current Directions in Psychological Science, 14(4), 220-223.

Coleman, J. S. (1988). Social capital in the creation of human capital. . American Journal of Sociology, S95-S120.

Conger, J. A., \& Kanungo, R. N. (1988). The empowerment process: Integrating theory and practice. Academy of Managmeny Review, 13, 471-482.

Damanpour, F. (1991). Organizational innovation: A meta analysis of effects of determinants and moderators. Academy of Management Journal, , 34(3), 555- 590.

David, F. R. (2011). Strategic Management Concept and Cases 13th ed. Florence, South California: Pearson Education Limited. 
Day, G. (1994). The capabilities of market-driven organisations. Journal of Marketing, 58(3), 37-52.

Dunford, B., Snell, S., \& Wright, P. (2009). Human Resources and the Resource Based View of the Firm. Strategic Human Resource Management, 76.

Finegold, D., \& Frenkel, S. (2006). Managing people where people really matter: the management of human resources in biotech companies. The International Journal of Human Resource Management, 17(1), 1-24.

Florin, J. L. (2003). A social capital model of high-growth ventures. Academy of Management Journal, , 46(3), 374- 384.

Freel, M. (2000). External linkages and product innovation in small manufacturing firms. Entrepreneurship and Regional Development, 12, 245-266.

Ghoshal, S. (1994). Linking organizational context and managerial action: the dimension of quality of management. Strategic Management Journal , 15: 91-112.

Hackman, J. R., \& Oldham, G. R. (1980). Work Design.

Heide, M., Gronhaug, K., \& Johannessen, S. (2002). Exploring barriers to the successful implementation of a formulated strategy. Scand. Journal of Management, 18, 217-231.

Hooley, G., Broderick, A., \& Möller, K. (1998). Competitive positioning and the resource-based view of the firm. Journal of Strategic Marketing, 6, 97-1 15.

Hitt, R. E. (2011). Concepts and Cases, Mason, OH. Management of Strategy .

Huselid, M. (1995). The Impact of Human Resource Management on Turnover,

Productivity, and Corporate Performance. Academy of Management Journal, 38,

635-72.

Huselid, M. A., Beatty, R. W., \& Becker, B. E. (2005). " A Players" or "A Positions"? The Strategic Logic of Workforce Management . Harvard Business Review.

Huselid, M., Jackson, S., \& Schuler, R. (1997). Technical and Strategic Human Resource Effectiveness as Determinants of Firm Performance. Academy of Management Journal, 40, 171-88.

Inyang, B. J. (2010). Strategic Human Resource Management (SHRM): A Paradigm Shift for Achieving Sustained Competitive Advantage in Organization. International Bulletin of Business Administration, 7, 1-14.

Jacobs, J. (1961). The death and life of great American. Women, minorities, and employment discrimination: , 153-186.

Johannessen, S. (2002). Exploring barriers to the successful implementation of a formulated strategy. Journal of Management, vol. 18, pp. 217-231.

Kaplan, R. S. and Norton, D. P. (2005). Creating the office of strategy management. Harvard Business Review, vol. 83, no. 10, pp. 72-80

Kramar, R. (1992). Strategic human resource management: are the promises fulfilled? Asia Pacific Journal of Human Resources, 30(1).

Kumar, V., Jones, E., \& Venkatesan, R. \&. (2011). Is Market Orientation a Source of Sustainable Competitive Advantage or Simply the Cost of Competing? Journal of Marketing, 75, 16-30. 
Lengnick-Hall, M. L., Lengnick-Hall, C. A., Andrade, L. S., \& Drake, B. (2009). Strategic human resource management: The evolution of the field. Human Resource Management Review, 19, 64-85.

L. K. Johnson. (2004). Execute your strategy-Without killing it. Harvard Management Update, pp. 3-5.

Loury, G. (1977). A dynamic theory of racial incom differences. Women, minorities, and employment discrimination Lexington, MA: Lexington.

Mello, J. A. (2002). Strategic Human Resource Management.

Nahapiet. (1997). Social capital, intellectual capital and the creation of value in firms. Academy of Management Best Paper Proceedings , 35-39.

Norton, R. S. (2008). The Execution Premium: Linking Strategy to Operations for Competitive Advantage. Boston, MA: Harvard Business School Press, .

Olsona, E. M., Slater, S. F., \& Hult, G. T. (2005). The importance of structure and process to strategy implementation. Business Horizons, 48, 47-54.

Pisano, G. \&. (1997). Dynamic capabilities and st rategic management. . St rategic

Management Journal, , 18(7) , 509-533.

Prahalad, C., \& Hamel, G. (1990). The core competence of the corporation. Haward Business Review, 68, 79-91.

Putnam, R. D. (1995). Bowling alone: America's declining social capital. Journal of Democracy, , 6: 65-78.

Putnam, R. D. (1993). The prosperous community: Socia lcapital and public life. American Prospect, 13: 35-42.

Ray, G., Barney, J. B., \& Muhanna, W. A. (2004). Capabilities, business processes, and competitive advantage: Choosing the dependent variable in empirical tests of the resource-based view. Strategic Management Journal, 25, 23-37.

Richard, O. C., \& Johnson, N. (2001). Strategic human resource management effectiveness and firm performance. International Journal of Human Resource Management, 12(2), 299-310.

Russo, M., \& Fouts, P. (1997). A Resource-Based Perspective on Corporate Environmental Performance and Profitability. Academy of Management Journal, 40, 534-59.

Saavedra, R., \& Kwun, S. K. (2000). Affective states in job characteristics theory.

Schuler, R. S., \& Jackson, S. (1987). Linking competitive strategies with human resource management practices. Academy of Management Executive, 1, 207-219.

Slater, E. O. (2010). "Worried about strategy implementation? Don't overlook marketing's role. Business Horizons, vol. 53, pp.469-479.

Snell, S., \& Dean, J. (1992). Integrated Manufacturing and Human Resource Management: A Human Capital Perspective. Academy of Management Journal, 35, 467-504.

Snell, S., Shadur, M., \& Wright, P. (2001). Human resources strategy: the era of our ways. In: M.A. Hitt, R.E. Freeman, and J.S. Harrison (eds) Handbook of Strategic Management. 627-649.

Sorooshian, S., Norzima, Z., Yusof, I., \& Rosnah, Y. (2010). Effect Analysis on Strategy Implementation Drivers. World Applied Sciences Journal, 11(10), 1255-1261. 
Spreitzer, G. (1995). Psychological empowerment in the workplace: Dimensions, measurement, and validation. Academy of Management Journal, 38, 1442-1465.

Sterling, J. (2003). Translating strategy into effective implementation: dispelling the myths and highlighting what works. Strategy \& Leadership, 31(3), 27-34.

Thompson, J., \& Martin, F. (2005). Strategic Management.

Tichy, N., Fombrun, C., \& DeVanna, M. (1982). Strategic human resource management. Sloan Managment Review, 23, 47-61.

Baker, W. (1990). Market networks and corporate behavior. American Journal of Sociology, , 96; 589-625.

Burt, R. S. (1992). Structural hales: The social structure of competition. Cambridge, MA:

Harvard University Press .

Coleman, J. S. (1988). Social capital in the creation of human capital. . American Journal of Sociology, S95-S120.

Damanpour, F. (1991). Organizational innovation: A meta analysis of effects of determinants and moderators. Academy of Management Journal, , 34(3), 555- 590.

David, F. R. (2011). Strategic Management Concept and Cases 13th ed. Florence, South California: Pearson Education Limited.

Florin, J. L. (2003). A social capital model of high-growth ventures. Academy of Management Journal, , 46(3), 374- 384.

Ghoshal, S. (1994). Linking organizational context and managerial action: the dimension of quality of management. Strategic Management Journal , 15: 91-112.

Jacobs, J. L. (1961, 1977). Tbe death and life of great American Cities. New York random House , 153-186.

Jacobs, J. (1961). The death and life of great American. Women, minorities, and employment discrimination: , 153-186.

Johannessen, S. (2002). Exploring barriers to the successful implementation of a formulated strategy. Journal of Management, vol. 18, pp. 217-231.

L. K. Johnson. (2004). Execute your strategy-Without killing it. Harvard Management Update, pp. 3-5.

Lin, N. \&. (1986). Access to occupations.

Loury, G. (1977). A dynamic theory of racial incom differences. Women, minorities, and employment discrimination Lexington, MA: Lexington.

Hitt, R. E. (2011). Concepts and Cases, Mason, OH. Management of Strategy .

Heide, K. G. (2002). Exploring barriers to the successful implementation of a formulated strategy. journal of Management, vol. 18, pp. 217-231.

Nahapiet. (1997). Social capital, intellectual capital and the creation of value in firms.

Academy of Management Best Paper Proceedings , 35-39.

Nahapiet, J., \& Ghoshal, S. (1998). Social capital, intellectual capital, and the organizational advantage. Academy of Management Review, 23(2), 242-266.

Norton, R. S. (2008). The Execution Premium: Linking Strategy to Operations for Competitive Advantage. Boston, MA: Harvard Business School Press, .

Pisano, G. \&. (1997). Dynamic capabilities and st rategic management. . St rategic Management Journal, , 18(7) , 509-533. 
Putnam, R. D. (1995). Bowling alone: America's declining social capital. Journal of Democracy, , 6: 65-78.

Putnam, R. D. (1993). The prosperous community: Socia lcapital and public life. American Prospect, 13: 35-42.

Ruekert, R. W. (1987). Marketing's interaction with other functional units: A conceptual framework and empirical evidence. Journal of Marketing, . , 51(1), 1 - 19.

Slater, E. O. (2010). "Worried about strategy implementation? Don't overlook marketing's role. Business Horizons, Kaplan, R. S. and Norton, D. P. (2005). Creating the office of strategy management. Harvard Business Review, vol. 83, no. 10, pp. 72-80.

Smith, k. G. (1994). Top management team demography and process:The role of social integration and communication. Administrative Science Quarterly, 39(3), 412-438.

Steele, M. C. (2005). Turning great strategy into great performance. Harvard Business Review, vol. 83, no. 7/8, pp. 64-72.

Sterling, J. (2003). Translating strategy into effective implementation: dispelling the myths and highlighting what works. Strategy \& Leadership, vol. 31, no. 3, pp. 27-34.

Tsai, W. (1998). Social capital and value creation: The role of int rafirm networks. Academy of Management Journal , 41(4), 464-477.

Wright, P. M., \& Boswell, W. R. (2002). Desegregating HRM: A review and synthesis of micro and macro human resource management research. Journal of Management, 28, 247-276.

Wright, P. M., \& McMahan, G. C. (1992). Theoretical Perspectives for Strategic Human Resource Management. Journal of Management, 18(2), 295-320.

Wright, P. M., \& McMahan, G. C. (2011). Exploring human capital: putting human back into strategic human resource management. Human Resource Management Journal, 21(2), 93-104.

Wright, P., Dunford, B., \& Snell, S. (2001a). Human resources and the resource based view of the firm. Journal of Management, 27, 701-721.

Wright, P., McMahan, G., \& McWilliams, A. (1994). Human resources as a source of sustained competitive advantage. International Journal of Human Resource Management,, 5, 299-324. 